\title{
Protected areas in Northern Colombia - on track to sustainable development?
}

\author{
Carla Marchant \& Axel Borsdorf
}

Keywords: sustainable development, livelihood, tourism, subsistence, coffee, Sierra Nevada de Santa Marta, Colombia

\section{Abstract}

On the way to more peace, Colombian biosphere reserves, national parks and privately owned protected areas have changed their main objective from conservation to becoming regions of sustainable development. On the basis of case studies in the Sierra Nevada de Santa Marta, Northern Colombia, this paper evaluates the concepts, strategies and measures by using the livelihood approach. The aim is to analyse if tourism and the export of cash crops like coffee can reduce the vulnerability of ecosystems and people. The study makes it clear that only on a small scale may tourism (eco-tourism and farm tourism) be regarded as a sustainable solution. This is also true of organic farming if it respects the natural ecosystems and does not pollute soil and water.
Profile

Protected area

Colombian biosphere reserves

Mountain range

Andes

Country

\section{Colombia}

\section{Introduction}

Colombia is often associated with civil war, drug cartels and violence. Press coverage in the second half of the $20^{\text {th }}$ century has painted a predominantly negative image of the North-Andean country. In recent years, however, Colombia has experienced a new departure: the security situation has improved greatly, the economy has grown strongly for some time and unemployment is going down. Colombia is a country undergoing change. This is not only true for its increasing integration in the global economy in the course of the neoliberal economic policy introduced in Colombia with the Uribe administration, but also in terms of climate change, which is making itself particularly felt in the Colombian mountain areas. Below we shall subsume the combination of climate change and globalization in the term global change.

Any change also means a risk, and risks include dangers that may develop into disasters. Stötter \& Monreal (2010: 92) call that a bad risk. At the same time, risks may also include options for a better future, what these authors call a good risk. In risky situations it is vital to look out for vulnerabilities, resilience and strategies of adaptation to the changing basic conditions in order to ensure sustainable development.

Protected areas (PAs), especially UNESCO biosphere reserves (BRs), are often called model regions of sustainable development (Lange 2005; UNESCO 2008, 2013). They are better suited than most places for testing development strategies aimed at a sustainable permanent improvement of the living conditions of the Colombian population while conserving the natural resources, ecosystems and ecosystem services as much as possible. Not just in the BRs, but also in IUCN-certified national parks (NPs) and in the many privately owned PAs in Colombia, which are protected by legislation, sustainability has been declared an implicit or explicit goal. In Colombia the various PA categories sometimes overlap. NPs may be part of larger BRs, and either may include private or corporate PAs of civil society.

Below we shall examine and assess the different development paths of Colombian PAs in terms of how they are adapting to global change by taking up the possibilities and reducing the dangers, and in how far they are capable of initiating sustainable developments. The adaptation options are manifold, they can be leveraged to secure subsistence, to develop tourism or to strengthen exports. In this process, models of governance and participation play an important role. For our study we chose PAs of various formats (BRs, NPs and PAs of civil society), all of them in mountain regions, which are affected in different ways by climate change at different altitudes and which have chosen different paths of adapting to globalization. Our main research question is thus:

Which challenges must be met to reduce vulnerability, encourage resilience and achieve sustainability?

An important aspect of change, as a result of the stabilizing situation in the country, is the growth of tourism. The rising figures for recent years are proof that tourism has become established by now and can be expected to continue in a positive vein. Not only more national but also, in spite of press coverage, more international tourists are travelling through Colombia (foreign incoming tourist arrivals doubled from 2004 to 2010 to 1.5 million; Baret 2011) and benefit at the same time from improvements in the infrastructure triggered by economic growth. Colombia is targeting ecological tourism in protected areas across the country. The subordinate question for this part of the study is therefore: Can tourism in Colombian PAs be pursued in a sustainable manner? What is the effect of farmers' cooperations offering ecotourism? 


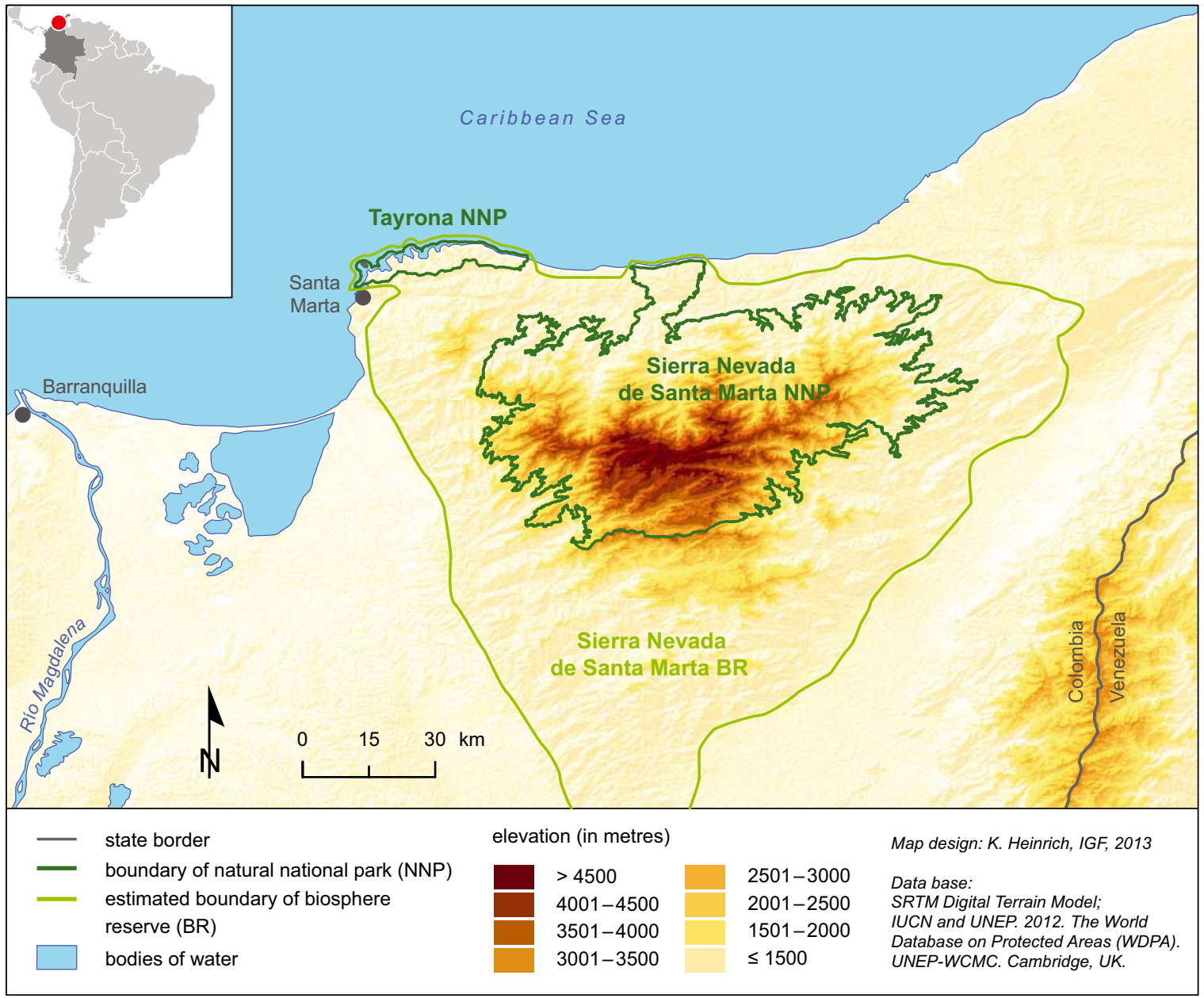

Figure 1 - Case study area.

A further, sustainable, development of PAs is the orientation on a cash crop to ensure constant economic growth. We will look at the coffee sector. As a result of the coffee crisis and the added competition from Southeast Asia on the global market, the local Colombian coffee farmers must make special efforts to be able to export their produce at prices that will secure their livelihood. In our case study we analysed the effect of unit size on production and marketing, and the opportunities for ecological products, taking into account the role of traditional (Coffea arabica) and new (hybrid) varieties (C. caturra, C. castilla, C. bourbon, C. colombia) as well as the policies of the national Federación Cafetera. The subordinate questions for this part of the study are therefore: Can Colombian coffee plantations be run sustainably, given the national conditions and the challenges of the world market? What role does unit size play in such efforts?

The third survival strategy we studied was agriculture aimed at securing livelihood, at subsistence and at market orientation. We also analysed if uniting small farmers in Asociaciones has any positive effect. In this respect, global change - climate change and global competition - is opening up numerous problems for the local farmers to deal with. Climate change or the dependence on the market are forcing the farmers to change their strategies and to look for solutions to their problems if they want to safeguard their livelihood. The subordinate questions for this part of the study are therefore: Can organic farming and the formation of Asociaciones contribute to sustaining the livelihood and to stabilizing the ecosystems? What is the role of an additional income from tourism?

\section{Study area}

Within a project module of the Institute for Geography at the University of Innsbruck, a group of students carried out a number of case studies in 2012. Here we only talk about Sierra Nevada de Santa Marta BR.

The UNESCO BR stretches across 2.1 million ha, includes Tayrona NP (56250 ha) and Sierra Nevada de Santa Marta NP (675000 ha) and with it the highest coastal cordillera in the world (the peaks Cristóbal Colón and Simón Bolívar at $5775 \mathrm{~m}$ each). From the coast to the glaciers it runs through all altitudinal zones of the tropical climate and the tropical vegetation. The páramo and the mountain forests are home to 96 endemic plant species and 104 endemic animal species (Tribin et al. 1999: 14, 18).

The PA is home to 211000 people, of whom 26500 are from the native ethnies of the Mayo-Kogui, Arhuaco, Wiwa, Wayuu and Kankwama (Tribin et al. 


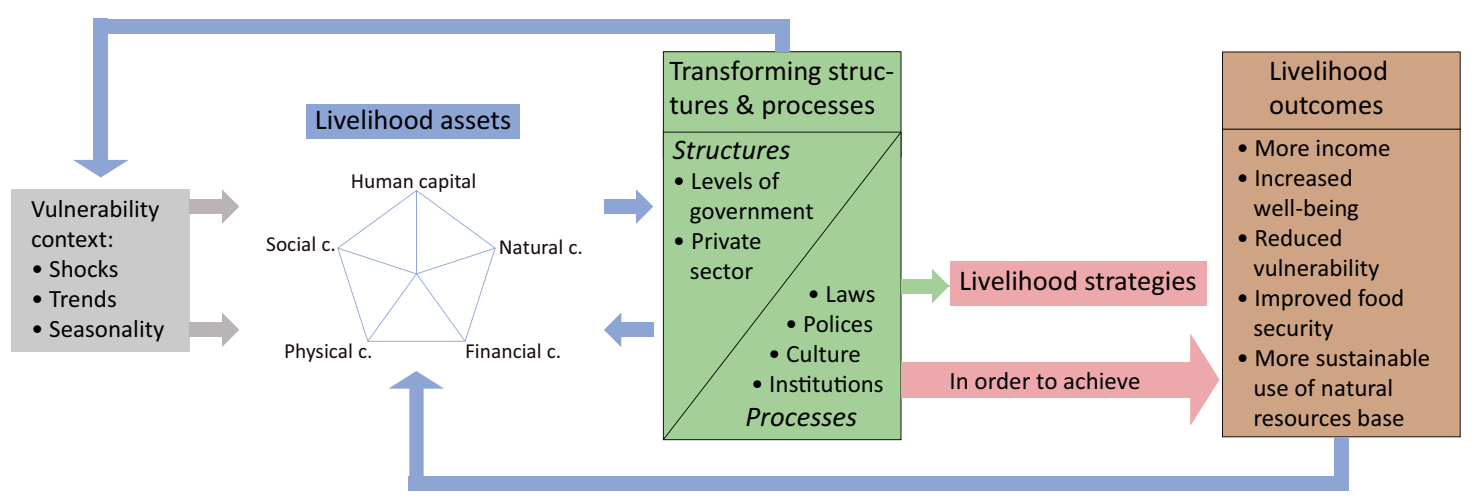

Figure 2 - Sustainable Livelihood Framework (after DFID 1999a, modified by the authors).

1999: 23f). The BR also includes various civil society PAs, of which we chose the protective corridor of Riotoribio as our case in point. It covers some 20000 ha and has been created to protect the habitat of rare and threatened birds (Pyrrbura viridicata; Strewe 2005) and the mountain landscape while providing sustainable development for the small farmers (Wüst 2006). It runs from the catchment area of the river on the San Lorenzo ridge $(3000 \mathrm{~m})$ to its estuary in the Caribbean Sea west of Santa Marta.

The study focused on tourism and coffee growing to allow a comparison with a study from 2011 in Cinturón Andino BR in Southern Colombia, which looked at the survival strategies of small farmers and native ethnies pursuing a subsistence economy (Borsdorf et al. 2011; Borsdorf 2012). This time the emphasis was on analysing the opportunities held by an orientation on export and international tourism and their compatibility with the environment and with social issues.

\section{Theoretical framework}

The livelihood approach is an analytical framework that tries to make livelihood systems, esp. those of poorer sections of the population, more sustainable and less vulnerable. Chambers \& Conway (1991) define livelihood as follows:

"A livelihood comprises the capabilities, assets (including both material and social resources) and activities required for a means of living. A livelihood is sustainable when it can cope with and recover from stresses and shocks and maintain or enhance its capabilities and assets both now and in the future, while not undermining the natural resource base."

In this approach the scale starts with a person and encompasses his / her household or their wider family system. The small scale means that this approach does not claim to be universally applicable or to explain the emergence of diversified or precarious livelihood systems. As the definition makes clear, the approach aims more at planning and controlling aspects.

Figure 2 presents the Sustainable Livelihood Framework. It studies the impact of positive and negative factors and interdependences of structures and processes on people's livelihood systems.
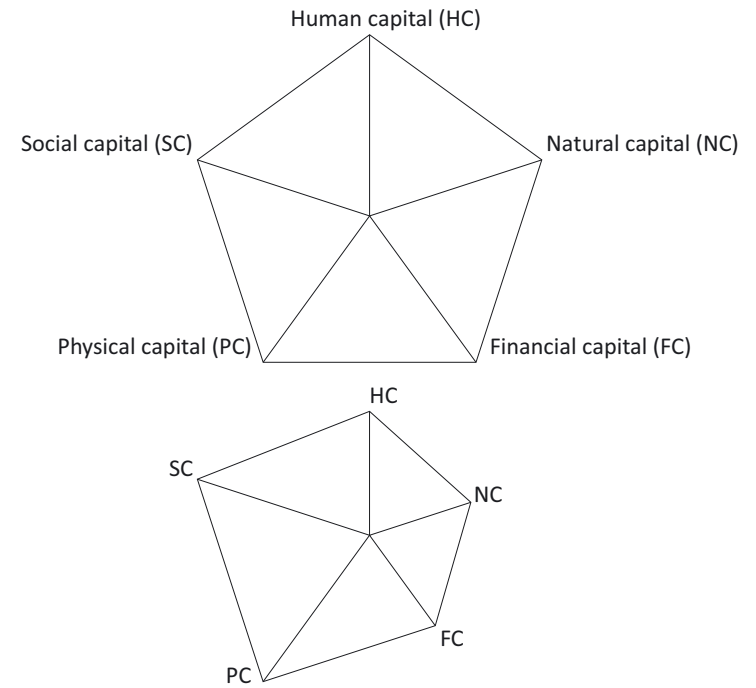

Figure 3 - Livelihood asset pentagon (DFID 1999b).

The framework aims to illustrate the connection between assets, framework conditions that may disintegrate into shocks that trigger vulnerability and into institutional / cultural structures, and the action strategies and meeting of needs (livelihood outcomes). Rauch (2009) describes the framework thus, "The livelihood framework takes into account the interdependence between structure and action. Its logic assumes that humans use their assets and react with their action strategies to environmental conditions, while taking into account the framework conditions, to achieve secure living conditions."

The vulnerability context includes environmental influences that are largely outside human control but may greatly affect livelihood security. Shocks might be natural disasters or famines, trends could be population growth or political developments and seasonality could be volatile prices or seasonal differences in employment options. The arrow from the institutional / cultural structures to the vulnerability context expresses the possibility of mitigating negative events (DFID 1999b).

Central element is an analysis of the livelihood assets, illustrated in the livelihood asset pentagon (Figure 3). It consists of human capital (knowledge, skills, capabilities, health), social capital (social networks, social systems of security), physical capital (infrastruc- 
ture, means of production, transport), financial capital (savings, access to credit) and natural capital (soil, climate, water; Ashley \& Carney 1999)

None of these capitals is sufficient on its own to achieve the diverse livelihood goals. The term capital must not be understood in the narrow economic sense but rather as resource on which to build a livelihood system.

In the centre of the pentagon there is no access to the relevant capital or the resource is missing. At the top of Figure 3 all capitals are fully present. The example on bottom illustrates an imbalance in the presence of the capitals.

In the last step of the Sustainable Livelihood Framework, the aim is to attain the Livelihood Outcomes by employing Livelihood Strategies (see Figure 2). Within the analytical framework of DFID, these Livelihood Strategies focus on the breadth and combination of human activities to secure a livelihood (Bohle 2001: 136). These may deviate within households and present great spatial, sectoral and temporal diversity (Krüger 2003: 11). The greater the choice of livelihood strategies, the better the adaptation and handling strategy vis-à-vis the vulnerability context. The range of agency is also greatly affected by the institutional and / or cultural structure. The Livelihood Outcomes represent a state of sustainably secured livelihood (Bohle 2001: 137). Outcomes to strive for are: improved earning situation, greater food safety, reduced vulnerability, increased wellbeing and increased sustainable use of natural resources.

We applied the livelihood approach to all case studies in order to be able to present a comparison of strengths and vulnerabilities.

\section{Methods}

In this study we used observation, mapping, literature and document analysis, data analysis, expert interviews, standardized surveys and satellite image analysis. The obtained data were then triangulated to mitigate the weaknesses of one method by the strengths of another (Figure 4).

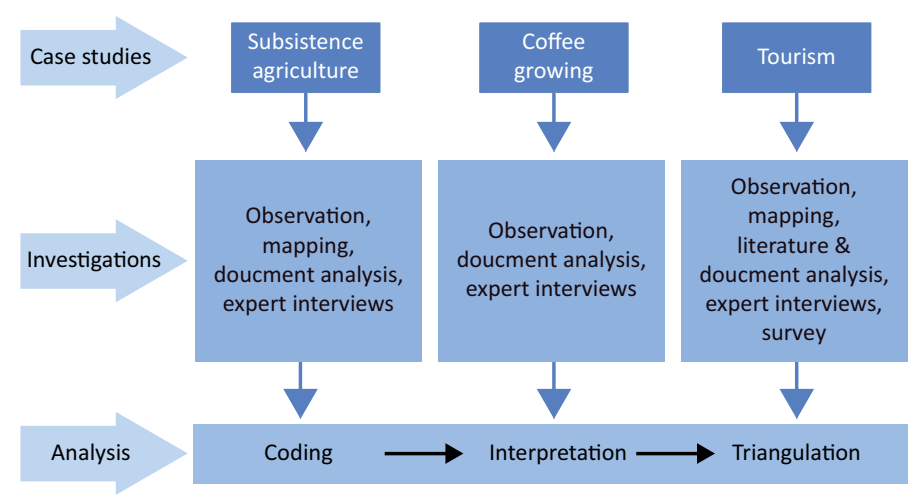

Figure 4-Methodology

\section{State of the art}

PAs are often model regions of sustainable development. This is particularly true for UNESCO BRs (Lange 2005). The objectives of BRs have been modified in the Seville Strategy (1995) and the Madrid Plan (UNESCO 2008). In Seville demands were raised for zoning and concrete development measures, in $\mathrm{Ma}$ drid it was decided to include urban regions. Colombia features a variety of PAs in addition to the BRs, most importantly the NPs, which fulfil the criteria of the IUCN category (Dudley 2008), and the PAs of the civil society, which are run by private individuals or NGOs (McNeely 1999).

In Colombia these PAs were the areas in which pacification of the population started. Militant activities of guerilla groups and paramilitaries (Steinmetz 2003), but also conflicts over land, triggered by differences in the legal system of indigenas (collective ownership) and campesinos (individual ownership), had cost many lives (Borsdorf 2011).

Manshard (1968) was the first to give a comprehensive overview of issues of tropical agriculture. Subsistence economy plays an important role in this context (Werlhof et al. 2003). In many Colombian PAs, campesinos and indigenas are still using this economic system with its orientation on self-sufficiency and little market participation (Borsdorf et al. 2013). In the BRs and in other PAs, however, strategies of developing tourism (Schunck 2011) and export of agricultural produce are also being pursued.

This is particularly true for coffee. As a cash crop, coffee has undergone dramatic changes in recent decades (Borsdorf 2007), triggered by the development of new hybrid varieties as part of the Green Revolution (Borsdorf 2006) and by the entry of new producer countries, such as India, Indonesia and Vietnam, into the world market. These changes have been further fuelled by changed consumer behaviour and new marketing strategies of the coffee roasters in the industrial countries (high pressure coffee makers, coffee capsules). In an effort to stave off Asian competition, the Federacion Nacional de Cafeteros converted the Colombian coffee industry completely to the new hybrid varieties and no longer accepts classic Arabica coffee at all. Large plantations could easily cope, small producers, however, were put under severe pressure.

Rappole et al. (2003) compare the pros and cons of shade-grown and sun-grown coffee, using examples from all over South America to explain different preservation methods. De la Hoz (1997) and Palacios (2002) provide an historic overview of coffee growing, including social, economic and political aspects.

\section{Results}

Case study: Coffee, Hacienda La Victoria

Today, the Hacienda la Victoria (founded in 1892) covers an area of 800 ha in the Tierra templada and Tier- 
ra fría (altitudinal zones between 800 and $2500 \mathrm{~m}$ ) of the Sierra Nevada de Santa Marta, 400 ha of which are protected forest (reserva forestal). The original extent of the farm was much bigger, but the precarious financial situation of the farm forced the owners to sell an area of 511 ha, which became the bird reserve Reserva Natural de las Aves El Dorado in March 2006.

To this day coffee growing is the only source of income at the hacienda. At altitudes between $800 \mathrm{~m}$ and $1450 \mathrm{~m}, C$. arabica and hybrid varieties, such as C. astilla, C. caturra and C. colombia, are grown. Most of the coffee plants, even of the hybrid varieties, are shade-grown (Figure 5).

Today 178 ha are planted up with coffee, however, 60 ha had to be cut down because of an infection with coffee rust. The fungal disease causes crop failure lasting two years. Currently the hacienda produces some $100000 \mathrm{~kg}$ of coffee on ca. 120 ha, i. e. about $800 \mathrm{~kg}$ of coffee per hectare. The hacienda aims to produce $140000 \mathrm{~kg}$ per year under ecological growing conditions.

The Sierra Nevada des Santa Marta offers all necessary natural conditions for coffee growing. The climate is tropical, with dry winters (Aw in Köppen / Geiger's classification). The growing areas are all situated at the altitudinal zone of the tropical mountain rainforest. Regionally the boundary with the Tierra templada is a bit lower, which means that coffee can be cultivated at relatively low altitudes of $800 \mathrm{~m}$ because of the humid air coming in from the sea and ample water supply. The land boasts 23 springs. In the course of climate change, however, weather and climate are beginning to change.

Despite the good conditions for growing coffee, it is not possible to do completely without fertilizer. Particularly the hybrid varieties, grown as monoculture and without shading trees, need regular feeds but the tropical soil cannot lock the nutrients in. Even in the Tierra templada partly consists of two layer clay minerals with low exchange capacity. In shade-growing this deficit is mitigated by the high-volume leaf mould of the shading trees, which retains the nutrients in the upper soil, from where it is transferred to the coffee plants through mycorrhizas.

The hacienda's coffee carries the international green seal because it is grown in a wholly ecological manner without the use of pesticides or artificial fertilizer. The plants are sprayed with a concoction that contains microorganisms in high concentration to encourage the nutrient circulation and to combat disease. First the microorganisms are washed out of an organic carrier, then oxygen is added to the solution so that the microorganisms multiply exponentially. The microorganisms speed up the formation of humus and regenerate nutrients which are then available to the plant and make it grow faster.

In addition, a mixture of earthworms and coffee cherry stone shells taken from coffee production are added to the soil. The earthworms loosen the soil and transform the stone shells into humus, thus returning

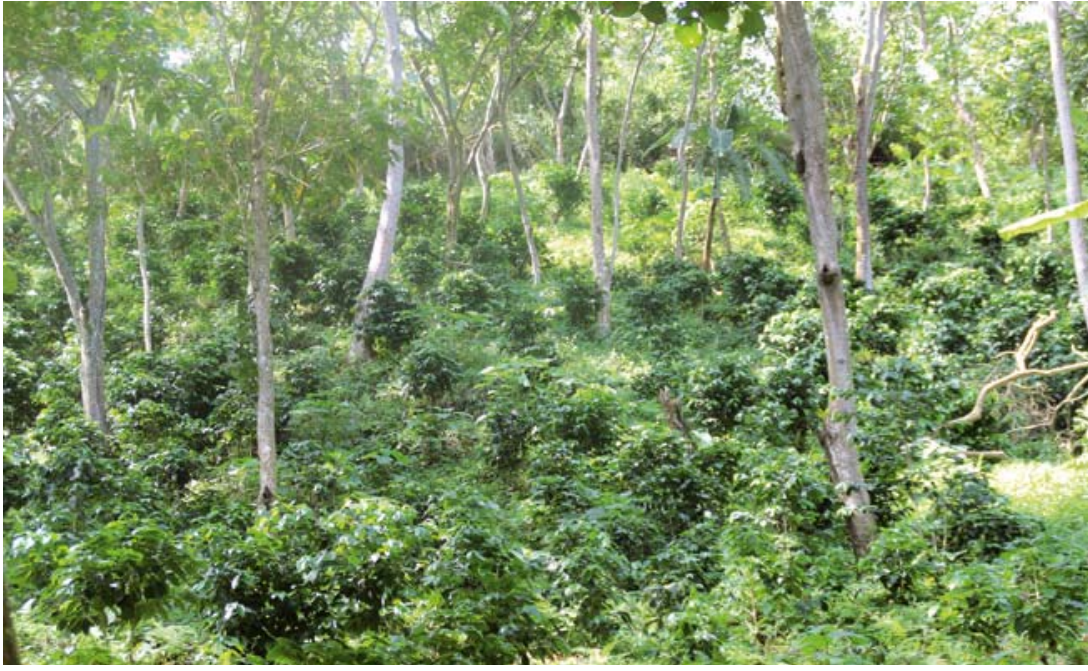

Figure 5 - Coffee grown in the shade of higher trees, Hacienda La Victoria. (C) A. Borsdorf

the nutrients from the shells to the coffee plant. In this way a closed nutrient cycle is being achieved.

The nutrients are taken up through mycorrhizas and made available to the plant. Mycorrhizas are root fungi that enable a symbiosis of plants and fungi. The mycorrhizas increase the contact area between plant and soil. This and the small diameter of the fungus hypha make more nutrients and water available to the plant (Blume et al. 2010: 98f). In this way the fungi prepare the nutrients for the plant, so there is no need to apply mineral fertilizers. As coffee is a permanent culture, the natural mycorrhizas are not destroyed and do not have to be artificially cultivated.

According to the law of declining growth of earnings, there is a logarithmic connection between the application of fertilizer and the growth of earnings. This means that as you approach highest yield additional application of fertilizer increases yield only very little and is not profitable (Gisi 1997: 261f). For La Victoria there is thus an economic as well as an ecological reason to forego artificial fertilizer. The third and last point is terrain and climate. The steep slopes on which the coffee is grown and the heavy rain during the wet season make for very unfavourable conditions for applying fertilizer on the surface. It would be washed away by the rains into the rivers and contribute to eutrophying them.

Like many plantation plants, coffee is prone to various diseases and pests, the most important of which is coffee rust (Hemileia vastarix), a fungal disease. The affected areas turn red and the leaves drop off. Diseased plants experience crop failure for two years. The C. castilla variety is largely resistent against this disease.

The most common pest in all coffee-producing countries is the coffee berry borer (Hypothenemus hamper), a beetle measuring ca. $1.5 \mathrm{~mm}$. It bores into the coffee cherry, where it lays its eggs for the offspring to grow. The males never leave the fruit. The coffee berry borer causes considerable damage. Yield drops as the cherries fall off. The affected cherries lose about 55\% 


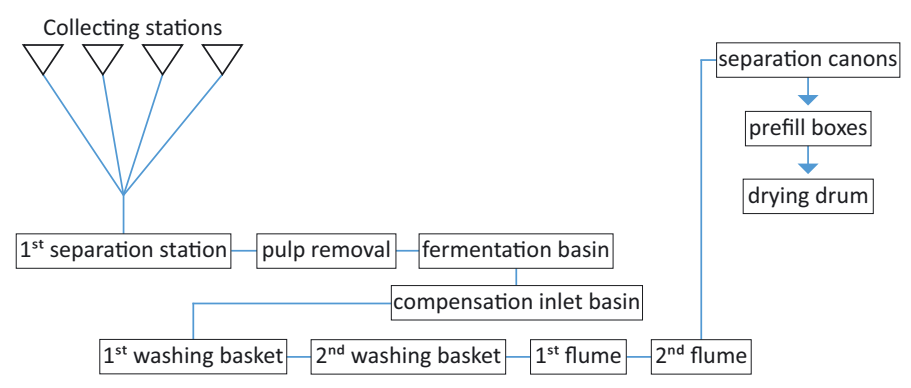

Figure 6 - Processing scheme by levels (Borsdorf \& Marchant 2013: 71).

of their weight and the end product is of much lower quality (Benavides 2012: 511f.).

The hacienda employes 25 permanent staff who work in the fields and in the factory. With their wives and children, a total of some 120 people live on La Victoria from coffee growing. During harvest time, seasonal workers bump up that number to 180 people. Maintenance of the coffee plants requires regular pruning by experts (Schröder 1991: 40). People are also needed for applying the organic fertilizer.

Coffee can be harvested by hand or by machine. In manual harvesting we distinguish two methods, i.e. picking and stripping. Picking means that only the ripe red cherries are harvested, leading to a higher quality end product. Stripping means stripping unripe, ripe and overripe coffee cherries as well as leaves and small branches off the plant, very similar to machine harvesting (Fischer 2005: 4). At La Victoria all harvesting is done by picking.

The seasonal migrant workers are paid by performance, measured in garrafon, a receptacle that holds about $14 \mathrm{~kg}$ of coffee cherries. On average a picker earns 50000 COP (ca. 21.50 EUR) per day. Harvesting is hard work in the steep terrain with coffee plants reaching more than $3 \mathrm{~m}$ in height sometimes.

Not all cherries on a coffee plant ripen at the same time. Two to three rounds of harvesting are necessary to catch all cherries when they are ripe. The annual harvest lasts from mid-November into February, sometimes even March, and is largely identical with the dry season, in the Sierra Nevada de Santa Marta lasting from December to March. Coffee processing is shown in Figure 6.

Currently most the coffee produced at the hacienda is exported to Europe directly via a bulk buyer, without any marketing through the Federacion Nacional de Cafeteros de Colombia. Some coffee is exported to the USA and to Japan. It is high-quality coffee, which means it is too good or too expensive for the Colombian home market. Future marketing is to be done via e-commerce. The owner is currently negotiating with an importer in London, who will sell the coffee on to German roasters, among others. But before this scheme can start, sufficient demand must be generated. The necessary marketing is currently under way. It remains to be seen if this strategy is successful.

In terms of the livelihood approach, Hacienda La Victoria is well endowed with natural capital and the

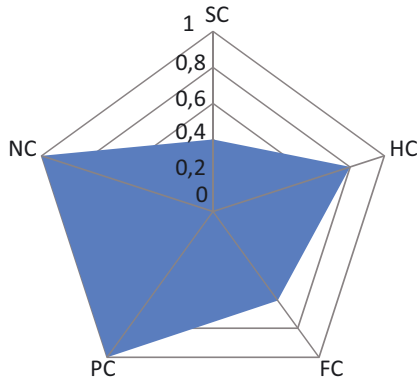

Figure 7 - Livelihood pentagon of Hacienda La Victoria.

methods used will not diminish it (Figure 7). Human capital must also be considered very good, given the expertise of the owners. This also holds for the social capital: the workers are well looked after and in good accommodation, conflicts with guerillas and paramilitaries have ceased. The physical capital is old but still works and is very well suited to producing high-quality coffee. The system and the people involved are only vulnerable from the lack of financial capital. The direct marketing strategy to Europe can be understood as a step in the right direction.

\section{Case study: Tourism}

The Colombian region with the greatest potential for tourism is the Carribbean. Visitor numbers in the NPs illustrate the value of tourism for the study areas. Tayrona NP reported 241460 visitors in 2011, while Sierra Nevada de Santa Marta NP has as yet hardly been opened up for tourism. In 2011 just 325 people visited it (Ministerio de Ambiente y Desarollo Sostenibilidad 2011), which adds up to a total of nearly 242000 visitors in that year for the BR.

Colombia focuses on ecotourism in an effort to encourage sustainable development. One such measure is uniting several farmers in a cooperative with a joint eco-tourist offering. In the study area the Asocición de Fincas Turísticas (ASOFINTUR) is one such association.

Much effort is yet needed to raise awareness of the conservation aims and of sustainable tourism development with tourists and indigenous population alike. In a survey $(\mathrm{n}=79)$ visitors were asked, among other things, how familiar they were with the aims of the PAs. Slightly more than a quarter of interviewees were between the ages of 21 and 30, only $7 \%$ were of retirement age. $20 \%$ were foreigners and $80 \%$ were individual travellers. As expected, the average length of stay of the foreign tourists was, at 12.24 days, considerably longer than that of Colombian tourists, who only stayed for 6.41 days.

The interviewees rated the things on offer for tourists on a scale from 1 (very bad) to 10 (excellent) and presented a very positive image. $74 \%$ rated tourist offerings as good or very good, only $5 \%$ are not or less satisfied with it.

The survey was complemented by guided interviews with six tourism experts. It became clear that esp. in terms of information level there were great differences of perception. The experts thought that visi- 


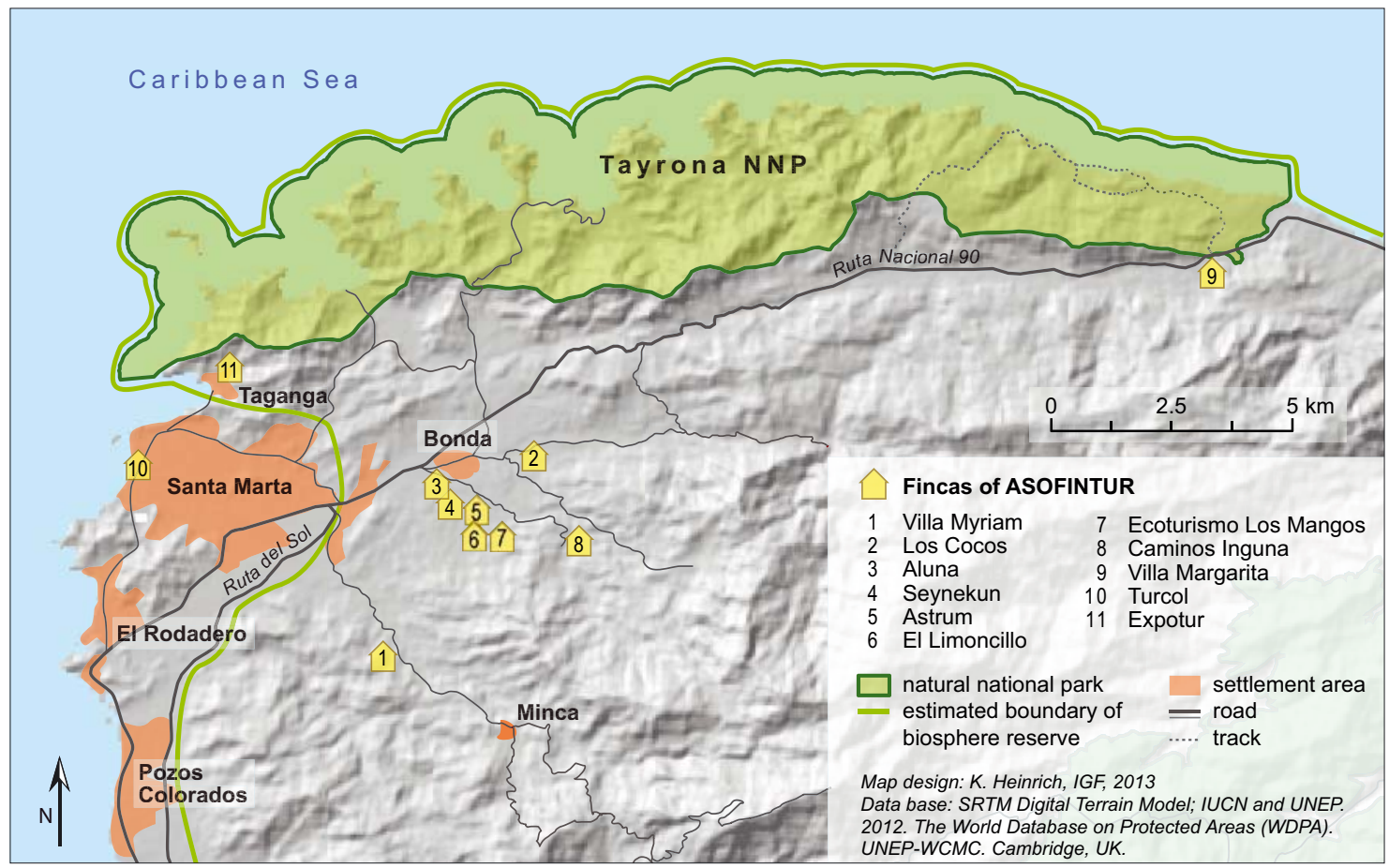

Figure 8-Location of the ASOFINTUR fincas (Bosdorf \& Marchant 2013: 56).

tors in general were well informed, while the survey showed that a majority $(65 \%)$ of visitors knew nothing about the PAs, with foreigners being considerably better informed $(70 \%$ of international tourists knew something about the conservation aims). Awareness of BRs, however, is much lower. Only $17.7 \%$ of foreigners and $9.7 \%$ of Colombians (in total $11.4 \%$ ) were able to name the aims of BRs. Of the PAs, only Tayrona NP has a stall with some superficial information on the peculiarities of the natural resources of the park. Neither Sierra Nevada NP nor the BR of the same name provide such information - a clear sign that information flow must be much improved to meet the education tasks of the park.

Some such efforts are under way in the 11 fincas united as ASOFINTUR (Figure 8). In addition to accommodation they offer activities that are easy on the environment, such as horse-riding, walking or mountain-biking. These additional earnings increase the financial capital of the fincas. The mostly foreign guests usually stay between two weeks and a month.

The physical and financial capital of the BR is not sufficiently strengthened by tourism due to the low visitor numbers, esp. in the mountains. Nor does it respect the valuable natural assets, except on the ASOFINTUR fincas, rather it is oriented on exploitation, which is not yet a problem, given the low visitor numbers. The human capital with the existing comprehensive and thorough local expertise is not being leveraged and the social capital is only strengthened inside ASOFINTUR (Figure 9). Tourism can only be called sustainable if information is improved, cooperation of the people involved tourism and the population strengthened and tourist infrastructure updated in an environmentally sensitive manner.
Case study: Riotoribio protective corridor

In the Riotoribio protective corridor, i. e. the hydrographical basin of the Río Toribio, tourism only plays a minor role. In our study we took the Finca La Cumbre as case in point. It covers an area of 62.5 ha, of which 30.5 ha are pasture, the rest is natural forest and is part of the association ASOTORIBIO (Asocición de Productores de el Corredor de Concervacion Rio Toribio Sierra Nevada de Santa Marta).

Woodland areas near the nesting grounds of the parrots are reserved for bird protection. The operational areas of the Finca La Cumbre start at $1850 \mathrm{~m}$ and reach elevations of nearly $2600 \mathrm{~m}$, i.e. most of the area falls into the altitudinal zone of the Tierra fria (from $2000 \mathrm{~m}$ ). Dairy cattle farming and cheese production is suitable for such conditions. A little below this finca is the Finca Vega, owned by the parents-inlaw of the owner of Finca La Cumbre. Finca Vega consists of a triangular farmstead at just below $1600 \mathrm{~m}$ and a small, 2.5 ha coffee plantation at $1700 \mathrm{~m}$, in the altitudinal zone of the Tierra templada, a favourable climate for growing coffee.

Currently (2012) it is planted up with the C. caturra variety, a hybrid variety of $C$. arabica. Harvesting started in 2008. In the coming years the coffee production is to be changed completely to organic farming. To this end shading trees have already been planted to protect the vulnerable coffee plants. To date there have been several attacks of coffee rust. A demucilaging and washing system has been installed. The beans are dried on the paved inner courtyard of the finca. The problem for small producers is the fact that powerful actors dictate selling conditions for the beans, which shrinks the expected profit of the producers. The Federacion Nacional de Cafeteros de Colombia is particularly keen to 

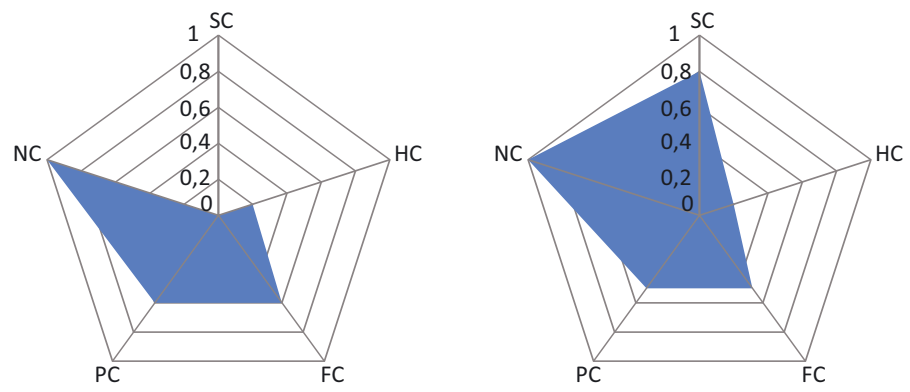

Figure 9 - Livelihood pentagons in tourism at Sierra Nevada de Santa Marta, left: coast, right: ASOFINTUR.
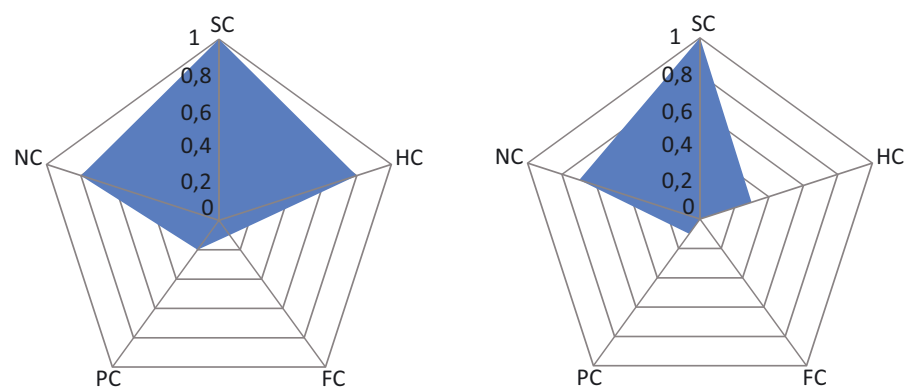

Figure 10 - Livelihood pentagons of ASOTORIBIO fincas. Left: Finca Vega, right: Finca La Cumbre.

impose its monopoly in exporting coffee to the world market. Many small producers would prefer marketing their coffee in the way the German organization Kaffee K.U.L.T. had planned to do it, where their product retains its high quality all the way to the end consumer, which would make the additional effort needed for ecological growing methods feasible.

This finca is linked by a track in bad repair to Minca and Santa Marta. In contrast, the Finca La Cumbre, near the spring of the Río Toribio, has no direct access to a track and can only be reached on foot or on horseback. The river drains the area to the west and flows into the Carribbean Sea some five kilometres northeast of the town of Ciénaga. The V-shaped valley created by fluvial processes has steep sides and hardly any good-sized flatter areas. The first proper settlement with central functions, such as primary school, shops and workshops, is Minca. By car it takes about 1.5 hours to drive the $20 \mathrm{~km}$ distance. After 37 kilometres and about 2.5 hours by car, the road reaches the coastal plain with the town of Santa Marta.

The spectacular mountain landscape and the fascinating tropical vegetation and diversity of species could attract many adventure tourists and bird watchers to the valley, but today there is little trace of them. The tourist infrastructure is currently being created and is mostly basic. At the Finca La Cumbre a guesthouse has been built in the hope for future visitors. At first many groups of students came, but these days there are only few visitors.

This makes the finca, like all the others within the protective corridor, dependent on earnings from agriculture and particularly from dairy farming. At three litres per cow per day, this is not very profitable and as the milk is only processed into a not very tasty kind of soft cheese (somewhere between feta und mozzarella), earnings remain low. Therefore the small farmers also produce honey and jam for an additional income. If they succeeded in producing a hard cheese instead of the soft cheese, which does not keep and is therefore not suitable for being sent to the markets in the cities, the earning situation would improve. Special attention needs to be paid to the microbial composition of the bacteria in culturing (Wüst 2006: 135).

The members of ASOTORIBIO also engage in reforestation with indigenous varieties of trees. By now 38 nurseries have been established and by August 2005 some 28000 trees had been planted (Wüst 2006: 138). Education in the locality is part of the project and carried out at the association meetings as well as in schools.

Here too we arrive at a mixed assessment in livelihood terms. The natural capital is now adequately protected and reforestation actually improves it further. Physical and financial capitals are week, making the livelihood of the valley inhabitants vulnerable. However, they have high human capital and in their association also high social capital (Figure 10).

\section{Discussion}

The three examples present different situations. In conservation terms, the efforts at both the export-oriented plantation La Victoria and the ASOTORIBIO must be seen positively. While the hacienda also has high physical capital, the ASOTORIBIO lacks physical capital, and both suffer from low financial capital. At the same time, both boast high human and social capital.

The outlook for tourist development is not so good. In these cases neither the education requirements of PAs are being met nor even the simplest control mechanisms implemented. This makes the flora and fauna more vulnerable than the humans. A responsible attitude towards the vulnerable, and in places already damaged, environment is missing, as are joint efforts and the use of participatory approaches in tourism, except for the members of ASOFINTUR, who combine business sense with idealism. A positive contrast is the love of nature and environmental awareness of the Weber family on La Victoria and the families in the Riotoribio protective corridor.

Overall, the balance is mixed. Unlike in the study on Río Piedras in Cinturón Andino BR (Borsdorf et al. 2011), tourism in the unchecked version practised in Sierra Nevada de Santa Marta and on the adjoining coast cannot be seen as sustainable development. Coffee, if grown organically under shading trees, however, can count as sustainable. It emulates the natural ecosystem and is profitable if it can be marketed directly to European distributors. 


\section{Conclusion}

The answer to our initial question is thus: to reduce vulnerability, encourage resilience and achieve sustainable regional development, it is necessary to expand organic farming and direct exports, given the difficult national marketing channels for coffee. Vulnerability can be reduced and sustainability achieved if the idea of conservation, which currently focuses on the habitats of rare birds, can be expanded to include conservation of the entire ecosystems and if the economic basis is strengthened through improving quality and export.

Tourism may be a main or an additional source of income, but it can only meet sustainability criteria if information on environmental protection and natural assets is improved, infrastructure is updated and visitor flows are channelled. Small-scale visitor management, for instance in the Asociaciones of the small farmers, is easier on the environment than mass tourism on the beaches.

Colombian coffee, if produced organically, has a market niche, particularly by offering the traditional $C$. arabica variety, which has all but disappeared from the world market. Coffee growing is ecologically sound if it emulates the natural ecosystem of the montane rain forest with mixed planting and shading trees, regardless of plantation size.

Campesino associations strengthen the economic base as well as human and social capital. They reduce the vulnerability of individual small farmers and can contribute to ecosystem conservation if they are oriented on PA criteria. Individual and ecotourism can add to the economic base.

\section{Acknowledgements}

The authors wish to thank all students involved in the fieldwork for their cooperation and their texts and visuals, some of which have been integrated in this paper. They were Michael Bürger, Benedikt Hora, Christoph Huber, Anika Maltzkait, Aaron Rabensteiner Ulrike Rödig, Elisabeth Schaber and Sina Starmans. Thanks are also due to the families who were such kind hosts and to the interviewed experts, as well as to Prof. Dr. Luis Alfonso Ortega of the Fundación Ecohabitats, who advised and helped us in situ.

\section{References}

Ashley, C. \& D. Carney 1999: Sustainable LiveliboodsLessons from Early Expericences. London

Balet, M. 2011. Die Tourismusentwicklung in Kolumbien. Ask! Arbeitsgruppe Schweiz-Kolumbien Monatsberichte. Available at http://www.askonline. ch/publikationen/monatsberichte/jahrgang-2011/ die-tourismusentwicklung-in-kolumbien/ (accessed 22/02/2013)

Bastidas, E.E.R. 2002. Biodiversidad y Turismo en el Marco del Conviento sobre la Diversidad Biólogica:
El caso del Parque Nacional Natural Tayrona, Departamento del Magdalena, Colombia. In: Rauschelbach, B., A. Schäfer \& B. Steck (eds.), Cooperating for Sustainable Tourism: 180-184. Heidelberg.

Benavides, P., C. Góngora \& A. Bustillo 2012. IPM Program to Control Coffee Berry Borer Hypothenemus hampei, with Emphasis on Highly Pathogenic Mixed Strains of Beauveria bassiana, to Overcome Insecticide Resistance in Colombia. In: Perveen, F. (ed.), Insecticides - Advances in Integrated Pest Management. 512-540. Rijeka.

Blume, H.-P., G.W. Brümmer, R. Horn, E. Kandeler, I. Kögel-Knabner, R. Kretzschmar, K. Stahr \& B.M. Wilke 2010. Scheffer / Schachtschabel - Lebrbuch der Bodenkunde. Heidelberg.

Bohle, H. 2001. Neue Ansätze der geographischen Risikoforschung. Ein Analyserahmen zur Bestimmung nachhaltiger Lebenssicherung von Armutsgruppen. Die Erde 132 (2): 119-140.

Borsdorf, A. 1997. Dritte Welt und Weltwirtschaft. Kurswissen Geographie. $4^{\text {th }}$ ed. Stuttgart.

Borsdorf, A. 2006. Espresso und Kokain. In: Borsdorf, A. \& W. Hödl (eds.), Naturraum Lateinamerika. Geographische und biologische Grundlagen: 357-372. Wien.

Borsdorf, A. 2007. Kaffee und Kokain. Globaler Markt und Konsumverhalten als Einflussfaktoren auf lateinamerikanische Ökosysteme und Kulturlandschaften. GW-Unterricht 106: 5-14.

Borsdorf, A. 2011. Peace through climate change adaptation - innovative paths in the Biosphere Reserve Cinturón Andino, Colombia. In: Borsdorf, A., J. Stötter \& E. Veulliet (eds.), Managing Alpine Future II. International Conference 21-23 November 2011, Congress Innsbruck. Abstracts: 78. Innsbruck.

Borsdorf, A., F. Borsdorf \& L.A. Ortega 2011. Towards climate change adaptation, sustainable development and conflict resolution - the Cinturón Andino Biosphere Reserve in Southern Colombia. eco.mont 3 (2): 43-48.

Borsdorf, A. \& M. Mergili (eds.) 2011. Kolumbien im Wandel. Erkenntnisse und Eindrücke einer dreiwöchigen Studienexkursion durch Zentral- und Südkolumbien. inngeo Innsbrucker Materialien zur Geographie 14. Innsbruck.

Borsdorf, A. \& C. Marchant (eds.) 2013. Kolumbien: Ein Land zwischen neoliberaler Öffnung und Nachbaltigkeit. Strategien der Regionalentwicklung im Zuge des Globalen Wandels anhand ausgewählter Beispiele an der Karibikküste. inngeo - Innsbrucker Materialien zur Geographie 15. Innsbruck.

Borsdorf, A., C. Marchant \& M. Mergili (eds.) 2013. Agricultura ecológicay estrategias de adaptación al cambio climático en la cuenca del Río Piedras. Popayán.

Chambers, R. \& G. Conway 1992. Sustainable rural livelihoods: Practical concepts for the $21^{\text {st }}$ century. IDS Discussion Paper 296. Brighton.

De la Hoz, V.J. 1997. Café Caribe: La economía cafetera en laSierra Nevada de Santa Marta. Cartagena. 
DFID (Department For International Development) 1999a. Sustainable Livelihoods Guidance Sheets (Section 1). Available at http://www.eldis.org/vfile/ upload/1/document/0901/section1.pdf (accessed 22/02/2013)

DFID (Department For International Development) 1999b. Sustainable Livelihoods Guidance Sheets (Section 2). Available at: http://www.eldis.org/vfile/ upload/1/document/0901/section2.pdf (accessed 22/02/2013)

Dudley, N. 2008. Guidelines for Applying Protected Area Management Categories. Gland.

Fischer, C. 2005. Kaffee Änderung physikalischchemischer Parameter beim Rösten, Quenchen und Mablen. Göttingen.

Gisi, U. 1997. Bodenökologie. Stuttgart.

Krüger, F. 2003. Handlungsorientierte Entwicklungsforschung: Trends, Perspektiven, Defizite. Petermanns Geographische Mitteilungen 147 (1): 6-14.

Lange, S. 2005. Inspired by Diversity. The Austrian Contribution to UNESCO's MAB programme. Created at the Institute for Urban and Regional Research. Vienna.

Manshard, W. 1968. Agrargeographie in der Tropen: eine Einfübrung. Mannheim.

McNeely, J.A. 1999. Mobilizing Broader support for Asia's Biodiversity: How Civil Society can Contribute to Protected Area Management.

Nolte, B. 2003. Die internationalen Richtlinien für nachhaltigen Tourismus und biologische Vielfalt im Rahmen der Biodiversitätskonvention. Greifswalder Beiträge zur Regional-, Freizeit- und Tourismusforschung 14: 205-212.

Ojeda, D. 2011. Whose Paradise? Conservation, Tourism and Land Grabbing in Tayrona Natural Park, Colombia. University of Sussex. Brighton.

Palacios, M. 2002. Coffee in Colombia, 1850-1970: An economic, social, and political history. Cambridge.

Rappole, J.H., D. King \& V. Rivera Vega 2003. Coffee and Conservation. Conservation Biology 17 (1): 334-336.

Rauch, T. 2009. Entwicklungspolitik - Theorien, Strategien, Instrumente. Das Geographische Seminar. Braunschweig.

Schröder, R. 1991. Kaffee, Tee und Kardamon. Tropische Genussmittel und Gewürze. Geschichte, Verbreitung, Anbau, Ernte, Aufbereitung. Stuttgart.

Schunck, I. 2009. Armutsbekämpfung durch Tourismus bleibt fragwürdig. Ein Beispiel anhand der ST-EP-Initiative der Welttourismusorganisation (UNWTO) in Kolumbien (Providencie/Santa Catalina).

Steinmetz, E. 2003. Naturschutz - (Aus-)Löser von Konflikten? Bundesamt für Naturschutz. Bonn.

Stötter, J. \& M. Monreal 2010. Mountains at risk. In: Borsdorf, A., G. Grabherr, K. Heinrich, B. Scott \&
J. Stötter (eds.), Challenges for Mountain Regions. Tackling Complexity: 86-93. Wien.

Strewe, R. 2005. Aktuelle Situation des SantaMarta-Rotschwanzsittichs in Kolumbien. Papageien 18: 94-97.

Tribin, M., N. Rodriguez \& M. Valderrama 1999. The biosphere reserve of the Sierra Nevada de Santa Marta: a pioneer experience of a bioregion. UNESCO Working papers South - South cooperation programme on environmentally sound socio-economic development in the humid tropics 30. Paris.

Thiel, L. \& D. Effler 2011. The Sierra Nevada de Santa Marta Biosphere Reserve, Colombia - The Origin of Coffee K.U.L.T. In: Austrian MAB Committee (ed.), Biosphere Reserves in the Mountains of the World. Excellence in the Clouds? 89-93. Wien.

Tribin, M.C.D.G., G.E.N. Rodríguez \& M. Valderrama 1999. The Biosphere Reserve of the Sierra Nevada de Santa Marta: A Pioneer Experience of a Shared and Coordinated Management of a Bioregion. Paris.

UNESCO 2008. Madrid Action Plan for Biosphere Reserves 2008-2013. Paris.

UNESCO 2013. Map of the World Network of Biosphere Reserves. Available at: http://www.unesco. $\mathrm{org} / \mathrm{new} / \mathrm{en} /$ natural-sciences/environment/ecological-sciences/ (assessed 15/01/2013)

Werlhof, C. v., V. Bennholt-Thomsen \& N. Faraclas 2003. Subsistenz und Widerstand. Alternativen zur Globalisierung. Wien.

Wüst, R. 2006. Käse kontra Kahlschlag - Artenschutz in Kolumbien. Papageien 4: 124-128.

\section{Authors}

\section{Carla Marchant}

studied geography at the Pontifical Catholic University of Chile (Santiago), has a Master's degree in Urban Studies and a PhD in Geography from the University of Innsbruck.

In 2013 she was appointed as a Professor of Geography at the School of Environmental Sciences, Faculty of Natural Resources at the Catholic University at Temuco, Chile. Contact: carla.marchant@gmail.com

\section{Axel Borsdorf}

studied geography, geology, early history and humanities at Göttingen, Valdivia / Chile and Tübingen. In 1991 he became a full professor at the Department of Geography, University of Innsbruck, and in 2006 director of IGF. His research interests are mountain science and man-environment interrelations. Contact: axel.borsdorf@oeaw.ac.at 